\title{
Review
}

Tatiana A. Mikhaylova*

\section{A comprehensive bibliography, updated checklist, and distribution patterns of Rhodophyta from the Barents Sea (the Arctic Ocean)}

https://doi.org/10.1515/bot-2021-0011

Received February 9, 2021; accepted April 15, 2021; published online April 30, 2021

\begin{abstract}
A lot of data on the flora of the Barents Sea are scattered in Russian publications and thus are largely inaccessible to many researchers. The study aims to compile a checklist and to verify the species composition of the Rhodophyta of the Barents Sea. The checklist is based on a comprehensive bibliographic study referring to a wide range of data on the species distribution, from the oldest to the most recent, indispensable for analyzing the temporal variability of the Barents Sea flora. A careful revision allows the report of 82 species of Rhodophyta, whereas 36 species have been excluded as belonging to doubtful records or misidentifications. The distribution of seven species in the Barents Sea is clarified. Seventeen species are widespread in the Barents Sea; 11 species are distributed locally. An extensive bibliography and data on the presence of the specimens in the herbarium of the Komarov Botanical Institute of the Russian Academy of Sciences are provided.
\end{abstract}

Keywords: Barents Sea flora; bibliography; red algae; revised checklist; Sørensen similarity index.

\section{Introduction}

The Barents Sea $\left(66^{\circ} 44^{\prime}-81^{\circ} 30^{\prime} \mathrm{N}, 16^{\circ} 30^{\prime}-68^{\circ} 32^{\prime} \mathrm{E}\right)$ is a marginal sea of the Arctic Ocean, located off the northern coasts of Norway and Russia, belonging to Norwegian and Russian territorial waters. The Barents Sea borders in the

*Corresponding author: Tatiana A. Mikhaylova, Department of Algology, Komarov Botanical Institute, Russian Academy of Sciences, Professora Popova Str., 2, Saint Petersburg 197376, Russia, E-mail: TMikhaylova@binran.ru. https://orcid.org/0000-0002-47400437 west with the Greenland Sea, in the southwest with the Norwegian Sea, in the south with the White Sea, and in the east, with the Kara Sea (Figure 1). The sea area is $1,424,000 \mathrm{~km}^{2}$, the average depth being $222 \mathrm{~m}$. In the southwesternmost area, where the Atlantic water mass prevails, the surface water temperatures in winter range from 3 to $5{ }^{\circ} \mathrm{C}$, in summer from 7 to $9^{\circ} \mathrm{C}$. This region of the Barents Sea remains ice-free all the year round. In other areas, where ice cover may appear, the absolute minimum is limited by the freezing point of $-1.8^{\circ} \mathrm{C}$. In the northern part of the sea, summer maximum of water surface temperature reaches $4-7{ }^{\circ} \mathrm{C}$, in the southeast part, $15-20^{\circ} \mathrm{C}$. During the year, surface water salinity ranges from 34.7 to 35.0 in the southwest, from 32.0 to 34.0 in the east and the north (Ecologicheskij Atlas 2020). A variety of ecosystems provides favorable habitats for seaweed growth.

The history of the study of the flora of the Barents Sea is described briefly below. The first specimens of the benthic algae from the Barents Sea were collected in 1837 and 1840 during the expeditions of Academician Karl Baer to Novaya Zemlya and the Kola Peninsula. These collections, as well as those of A. Schrenk (1854), were then used by Franz Ruprecht to summarize the data available at that time on the seaweeds of the "Ice Sea" stretching from Finnmark to the Beaufort Sea. In total, 52 species were indicated for the area of the modern Barents Sea (Postels and Ruprecht 1840). Christophor Gobi reported 76 species for the White Sea and the adjacent parts of the Arctic Ocean (Gobi 1878). Some information about marine algae of the Novaya Zemlya Archipelago and the Yugorsky Strait is found in publications of the 19th century (Heuglin 1874; Schrenk 1854; Sewell 1889; Zeller 1883). Studies of the benthic algae from Spitsbergen also have a long history (Fredriksen et al. 2019). Several Swedish surveys made a great contribution to the knowledge of seaweeds in this archipelago. In particular, Nordenskjöld's expeditions in 1872-1880 to Spitsbergen, Novaya Zemlya, and northern Siberia were especially productive, because the famous Swedish phycologist 


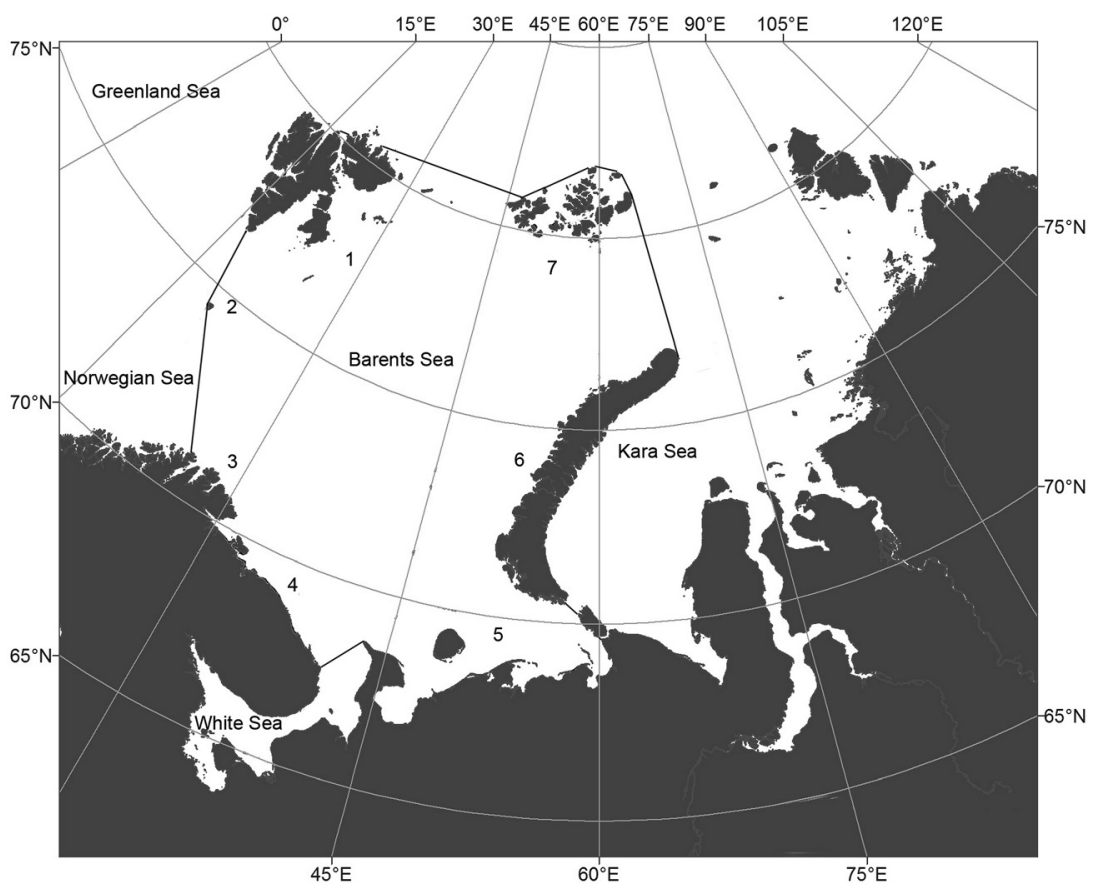

Figure 1: Schematic map of the Barents Sea. Symbols: 1, Spitsbergen; 2, Bear Island; 3, northern Norway; 4, Murman coast; 5 , southeastern part of the Barents Sea; 6 , Novaya Zemlya; 7, Franz Josef Land.
F.R. Kjellman was a member of the team. Kjellman published a number of works on algae from different regions of the Barents Sea based on the results of processing the collected materials and summarizing all available data (Kjellman 1875, 1877, 1883, 1903).

In the 20th century, Russian and Soviet phycologists made significant contributions to knowledge about the algae of the Barents Sea. The Murman coast is the best explored area. Regard must be paid to the floristic works of E.S. Sinova (1912, 1914, 1916a,b, 1926, 1933), which were continued by the floristic and taxonomic studies of her niece A.D. Zinova (1935, 1948, 1950, 1953b, 1955). Zinova may be considered rightfully the founder of the Soviet marine algological school. Her followers continued these researches successfully (Blinova 1964, 1965a,b, 1966; Grintal 1965; Perestenko 1963, 1964, 1983; Vinogradova 1961, 1964a,b, 2002, 2005a,b, 2007, 2010, 2011; Vinogradova and Shtrik 2005). Different floristic information and data on the biology and taxonomy of certain species of the Barents Sea may be obtained from recent publications (Averintseva and Shoshina 1990; Efimova 1990, 1995; Evseeva 2018; Kuznetsov and Schoschina 2003; Makarov and Shoshina 1986; Malavenda 2018; Malavenda and Makarov 2014; Malavenda and Metelskiy 2013; Malavenda et al. 2017; Markovskaya et al. 2016; Mikhaylova 2006, 2012; Mikhaylova and Shtrik 2007; Schoschina 1996, 1998; Shoshina 1991; Shoshina and Averintseva 1994; Shoshina and Makarov 1995; Shoshina et al. 1994). Information about the algae of the Norwegian coast of the Barents Sea was obtained from a range of publications over a hundred-year period (Børgesen and Jonsson 1908; Foslie 1881, 1890; Jaasund 1965; Rueness 1977, 1997; Simmons 1906).

Information on the algal flora on Bear Island is extremely scarce (Børgesen and Jonsson 1908; Kjellman 1883, 1903; Weslawski et al. 1997). Other areas remote from the vicinity of the marine biological stations were studied in a number of Soviet and Russian marine expeditions. As a result of these expeditions, new data were obtained on the algae of Novaya Zemlya (Evseeva 2018; Flerov 1932; Flerov and Karsakoff 1932; Gemp and Byzova 1970; Shirshov 1933; Shtric et al. 2000; Sinova 1929, 1956), Franz Josef Land (Averincev and Vinogradova 1990; Golikov and Averincev 1977; Terechova 1973; Vinogradova 1986, 1987; Vinogradova and Shoshina 1993) and the southeastern part of the Barents Sea (Averintseva 1996; Flerov and Karsakoff 1925; Korennikov and Gemp 1976; Korennikov and Shoshina 1980; Kucheruk et al. 2003; Metelskiy 2014; Mikhaylova 2006; Pushkin 1968).

Lists of Rhodophyta of the Barents Sea are presented in the publications of Gobi (1878), Kjellman (1883), Simmons (1906), Børgesen and Jonsson (1908), Sinova (1912, 1914, 1926), Zinova (1955), Kuznetsov and Schoschina (2003), Malavenda et al. (2017) and Evseeva (2018) where 29, 38, $63,66,71,75,62,74$, and 89 species of red algae were named, respectively. The number of Rhodophyta species reported for the Barents Sea has increased over time. However, the most recent census (Evseeva 2018) contains inaccuracies and thus requires clarification. In addition, 
there have been recent changes in the taxonomic status and nomenclature of some species.

Accurate and valid information on the distribution of species in the past and present is especially relevant in relation to the close attention now paid to changes in biodiversity. This study aims to provide complete information about when, under what names, and by whom the red algal species in the Barents Sea have been reported. The revised checklist comprises the data on the species distribution, covering a vast period from the oldest to the most recent publications, and aims to list the available literature for the region in full. Therefore, this checklist is a valuable source for analyzing the temporal variability of the Barents Sea flora.

\section{Materials and methods}

The checklist is based on comprehensive bibliographic material comprising both Russian and international publications that were screened for species records. The lists for the seaweeds of the Barents Sea (Børgesen and Jonsson 1908; Evseeva 2018; Kjellman 1883; Kuznetsov and Schoschina 2003; Malavenda et al. 2017; Simmons 1906; Sinova 1912; Zinova 1955) were used as a starting point to compile the revised checklist of the Rhodophyta of the Barents Sea. The physical presence of specimens in the herbarium of the Komarov Botanical Institute of the Russian Academy of Sciences, St. Petersburg (LE), was checked. Species records were excluded from the checklist if they were based on misidentifications or were not supported by sufficient evidence, such as published descriptions or herbarium specimens. Taxa of marine macroalgae reported in scientific books, journals and conference proceedings have been critically reviewed with regard to present-day taxonomy and nomenclature, mostly using the online data provided by the site AlgaeBase (Guiry and Guiry 2021). The taxonomy of Bangiales, Corallinales, Hapalidiales and Ceramiales is given with reference to the studies by Vinogradova (2002, 2005a,b, 2007, 2010, 2011).

The taxonomic arrangement of orders follows recent synoptic reviews of the classification of red algae (Schneider and Wynne 2007; Wynne and Schneider 2010). Within each order, the species are arranged alphabetically (Table 1, Supplementary Table S1). The distribution of species is listed for seven regions of the Barents Sea: Spitsbergen (the southern and eastern coasts), Bear Island, northern Norway (from the North Cape to the Varanger Peninsula), the Murman coast, the southeastern part of the Barents Sea (from the Kanin Nos Cape to the Kara Strait), Novaya Zemlya (the western coast), and Franz Josef Land (Figure 1). Data on the red algae of Spitsbergen without specifying the exact localities were also used (Agardh 1862, 1868a,b; Børgesen and Jonsson 1908; Heuglin 1874; Lindblom 1840; Simmons 1906). If the species from these sources were later found on the southern and/or eastern coasts of the archipelago (i.e. belonging to the Barents Sea), they are then also listed.

The floras of Rhodophyta of these seven areas of the Barents Sea were compared pairwise using the Sørensen similarity index: $C_{s}=(2 N a+b) /(N a+N b)$, where $N_{a}$, number of species in the first region; $N_{b}$, number of species in the second region; $N_{a+b}$, number of species in common for both regions (Magurran 1988).

\section{Results and discussion}

In consideration of the taxonomic and nomenclatural changes, as well as correcting inaccurate records, the list was reduced to 82 species (Table 1, Supplementary Table S1). The current names of the species and the number of references citing each species findings in different areas of the Barents Sea is presented in Table 1. The detailed data, i.e. the full reference list and all names under which the species were mentioned by the authors, are given in Supplementary Table S1. Mainly reliable records were included in this list. There are also 36 red algal species mentioned in the publications on the Barents Sea but excluded from the checklist for several reasons. The list of doubtful, unchecked, and misidentified species is presented and discussed in Supplementary Table S2.

The species of red algae included in the present checklist belong to 14 orders, the largest of which are Ceramiales (21 species), Gigartinales (16), Acrochaetiales (7), Palmariales (7), Corallinales (7), Hapalidiales (6), and Bangiales (6). The distribution of certain species in the Barents Sea is clarified below.

The record of Neodilsea integra in the Barents Sea as Dilsea integra (Zinova 1955: 66-67) refers to a specimen from the Murman coast named Sarcophyllis arctica by E.S. Sinova (1912: 259). Subsequently, A.D. Zinova (Zinova 1961a: 85) re-identified this specimen as belonging to the genus Rhodymenia; in the up-to-date census of the Arctic flora, this is the genus Palmaria. The only recent record of this Arctic species from the Murman coast (Evseeva 2018: 19), named by that author as Dilsea socialis, is doubtful because no voucher specimens have been presented by the author.

Børgesen and Jonsson (1908) reported Neopolyporolithon arcticum as Lithothamnion arcticum from the "Murman Sea" without providing exact coordinates of the sites of collection. Therefore, this record cannot be included in the present checklist.

Rhodomela sibirica A. Zinova et Vinogradova is reliably known only from the southeastern part of the Barents Sea (Kucheruk et al. 2003: 225; Malavenda et al. 2017: 344; Mikhaylova 2006; Vinogradova 2005b: 1055, 2011: 688). The new data about distribution of this species from the Murman coast and Novaya Zemlya (Evseeva 2018, 21) are doubtful because they have not been confirmed by herbarium specimens, their description, or illustrations.

The records of Plumaria plumosa (=Ptilota elegans) from the southeastern coast of the Barents Sea and Novaya Zemlya (Evseeva 2018: 20; Malavenda et al. 2017: 344) are doubtful because no voucher specimen was reported. 
Table 1: Numbers of references with species records, and the presence of the specimens in the herbarium of the Komarov Botanical Institute of the Russian Academy of Sciences, St. Petersburg (LE) for different regions of the Barents Sea.

No. Current names
Regions of the Barents Sea

SB BI N

MC

NZ

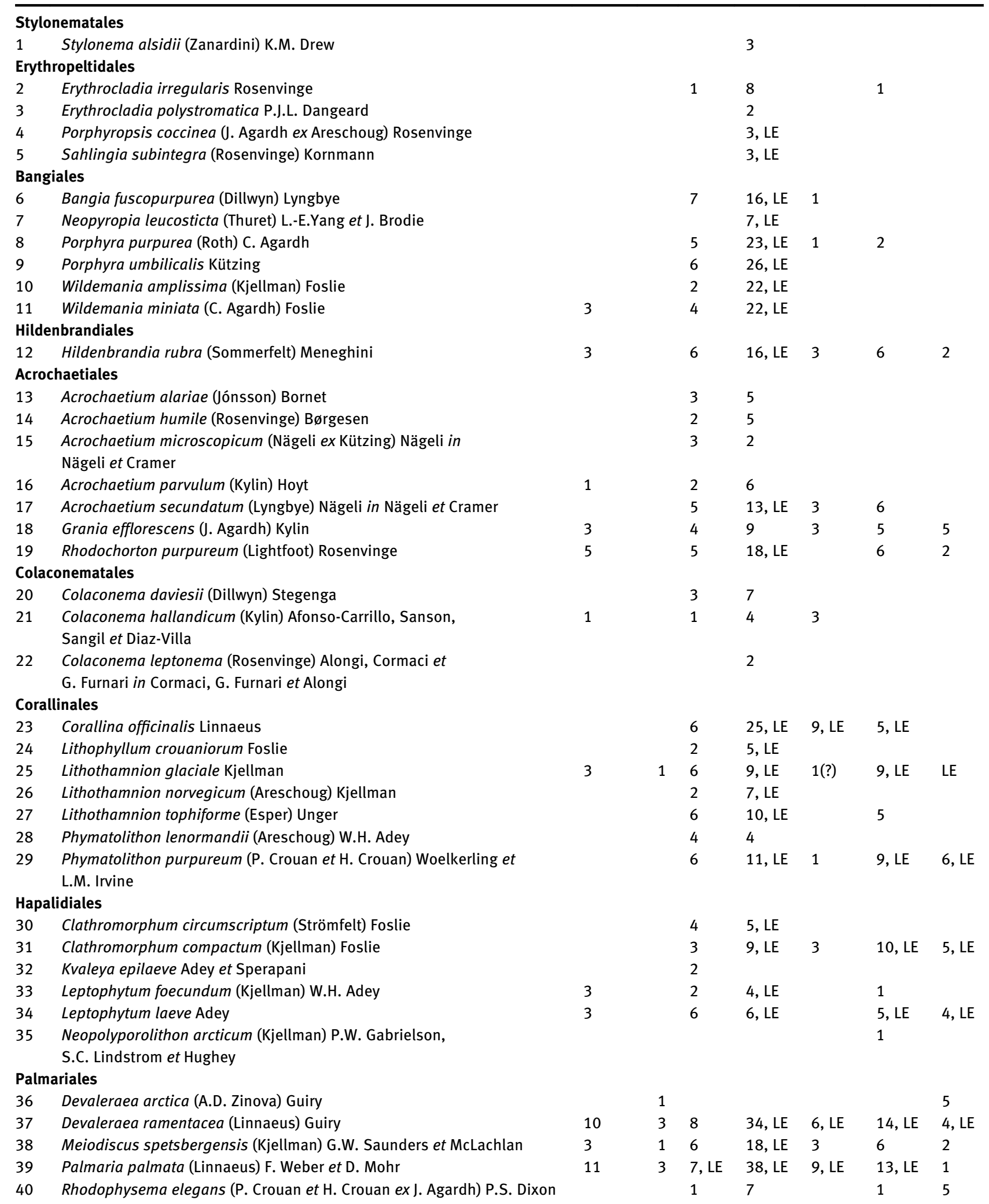


Table 1: (continued)

\begin{tabular}{|c|c|c|c|c|c|c|c|c|}
\hline \multirow[t]{2}{*}{ No. } & \multirow[t]{2}{*}{ Current names } & \multicolumn{7}{|c|}{ Regions of the Barents Sea } \\
\hline & & SB & BI & NN & MC & SE & NZ & FJ \\
\hline 41 & Rhodophysema lundii (Edelstein) C.W. Schneider et M.J. Wynne & & & 1 & 6 & & & 5 \\
\hline 42 & Rubrointrusa membranacea (Magnus) S.L. Clayden et G.W. Saunders & 1 & & 4 & 4 & & 2 & \\
\hline \multicolumn{9}{|c|}{ Ahnfeltiales } \\
\hline 43 & Ahnfeltia plicata (Hudson) E.M. Fries & 3 & & 5 & $13, \mathrm{LE}$ & 10, LE & 4 & \\
\hline \multicolumn{9}{|c|}{ Bonnemaisoniales } \\
\hline 44 & Bonnemaisonia hamifera Hariot & & & 1 & 2 & & & \\
\hline \multicolumn{9}{|c|}{ Ceramiales } \\
\hline 45 & Antithamnionella floccosa (O.F. Müller) Whittick & & 1 & 6 & 19, LE & 1 & 1 & \\
\hline 46 & Ceramium deslongchampsii Chauvin ex Duby & & & 6 & 9, LE & 5 & 4 & \\
\hline 47 & Ceramium virgatum Roth & 4 & & 7 & $33, \mathrm{LE}$ & 9, LE & $13, \mathrm{LE}$ & \\
\hline 48 & Choreocolax polysiphoniae Reinsch & & & 3 & 6, LE & & & \\
\hline 49 & Delesseria sanguinea (Hudson) J.V. Lamouroux & & & 7 & $22, \mathrm{LE}$ & 1 & 4, LE & 7 \\
\hline 50 & Gaillona scopulorum (C. Agardh) Athanasiadis & & & 3 & & & & \\
\hline 51 & Harveyella mirabilis (Reinsch) F. Schmitz et Reinke in Reinke & & & 5 & 9, LE & 4 & 5 & \\
\hline 52 & Membranoptera alata (Hudson) Stackhouse & 2 & 1 & 6 & 20, LE & & & \\
\hline 53 & Membranoptera fabriciana (Lyngbye) M.J. Wynne et G.W. Saunders & 7 & 2 & 3 & $16, \mathrm{LE}$ & 7, LE & 9, LE & \\
\hline 54 & Odonthalia dentata (Linnaeus) Lyngbye & 10 & 3 & 8 & 34, LE & 14, LE & 19, LE & 7 \\
\hline 55 & Phycodrys rubens (Linnaeus) Batters & $13, \mathrm{LE}$ & 3 & 7 & 33, LE & $18, \mathrm{LE}$ & $18, \mathrm{LE}$ & 8, LE \\
\hline 56 & Plumaria plumosa (Hudson) Kuntze & & & 6 & $15, \mathrm{LE}$ & & & \\
\hline 57 & Polysiphonia stricta (Mertens ex Dillwyn) Greville & 3 & & 9 & $37, \mathrm{LE}$ & 10, LE & $12, \mathrm{LE}$ & 7 \\
\hline 58 & Ptilota gunneri P.C. Silva, Maggs et L.M. Irvine in Maggs et Hommersand & 7 & & 8 & $31, \mathrm{LE}$ & 9, LE & $16, \mathrm{LE}$ & 6 \\
\hline 59 & Ptilota serrata Kützing & 6, LE & 2 & 7 & $22, \mathrm{LE}$ & $10, \mathrm{LE}$ & $13, \mathrm{LE}$ & \\
\hline 60 & Rhodomela confervoides (Hudson) P.C. Silva & 8 & & $8, \mathrm{LE}$ & $36, \mathrm{LE}$ & $12, \mathrm{LE}$ & $14, \mathrm{LE}$ & 5 \\
\hline 61 & Rhodomela sibirica A.D. Zinova et Vinogradova in Vinogradova & & & & & 5 & & \\
\hline 62 & Savoiea arctica (J. Agardh) M.J. Wynne & 11 & 1 & 8 & $27, \mathrm{LE}$ & 12, LE & $16, \mathrm{LE}$ & 10, LE \\
\hline 63 & Scagelia pylaisaei (Montagne) M.J. Wynne & 6 & & 7 & 20, LE & 8 & $12, \mathrm{LE}$ & \\
\hline 64 & Vertebrata fucoides (Hudson) Kuntze & 2 & & 7 & $21, \mathrm{LE}$ & 9, LE & 3, LE & \\
\hline 65 & Vertebrata lanosa (Linnaeus) T.A. Christensen & & & 7 & $22, \mathrm{LE}$ & & & \\
\hline \multicolumn{9}{|c|}{ Gigartinales } \\
\hline 66 & Chondrus crispus Stackhouse & & & 6 & 16 & 1 & 1 & \\
\hline 67 & Coccotylus brodiei (Turner) Kützing & & 1 & 3 & $14, \mathrm{LE}$ & 7, LE & $11, \mathrm{LE}$ & \\
\hline 68 & Coccotylus hartzii (Rosenvinge) Le Gall et G.W. Saunders & & & 2 & 4 & 4 & 3 & \\
\hline 69 & Coccotylus truncatus (Pallas) M.J. Wynne et J.N. Heine & 9 & 1 & 5 & 20, LE & $10, \mathrm{LE}$ & $15, \mathrm{LE}$ & 7 \\
\hline 70 & Cystoclonium purpureum (Hudson) Batters & & & 6, LE & 20, LE & 6, LE & 4, LE & \\
\hline 71 & Dilsea carnosa (Schmidel) Kuntze & & & 1 & 7 & 2 & 3 & 1 \\
\hline 72 & Dumontia contorta (S.G.Gmelin) Ruprecht & 2 & & 7 & $22, \mathrm{LE}$ & 1, LE & & \\
\hline 73 & Euthora cristata (C. Agardh) J. Agardh & 9 & 2 & 7 & 28, LE & $12, \mathrm{LE}$ & $13, \mathrm{LE}$ & 5 \\
\hline 74 & Fimbrifolium dichotomum (Lepechin) G.I. Hansen & 5 & 2 & 7, LE & $26, \mathrm{LE}$ & 9, LE & 7, LE & \\
\hline 75 & Furcellaria lumbricalis (Hudson) J.V. Lamouroux & & & 7 & $13, \mathrm{LE}$ & 6, LE & 6, LE & \\
\hline 76 & Haemescharia hennedyi (Harvey) K.L. Vinogradova et Yacovleva & & & & 1 & & & \\
\hline 77 & Mastocarpus stellatus (Stackhouse) Guiry in Guiry et al. & & & 5, LE & 7 & & & \\
\hline 78 & Neodilsea integra (Kjellman) A.D. Zinova & 6 & 1 & & & 9, LE & $16, \mathrm{LE}$ & \\
\hline 79 & Petrocelis middendorfii (Ruprecht) Kjellman & & & 3 & 2 & & 3 & \\
\hline 80 & Polyides rotunda (Hudson) Gaillon & & & 5 & $22, \mathrm{LE}$ & $10, \mathrm{LE}$ & 9, LE & \\
\hline 81 & Turnerella pennyi (Harvey) F. Schmitz in Rosenvinge & 8 & 1 & 5 & $16, \mathrm{LE}$ & & 7, LE & \\
\hline \multicolumn{9}{|c|}{ Peyssonneliales } \\
\hline 82 & Peyssonnelia rosenvingei $\mathrm{F}$. Schmitz in Rosenvinge & & & 2 & 4 & & 3, LE & \\
\hline \multicolumn{2}{|c|}{ Total species for each region } & 32 & 18 & 71 & 76 & 42 & 49 & 23 \\
\hline
\end{tabular}

Symbols: SP, Spitsbergen; BI, Bear Island; NN, northern Norway; MC, Murman coast; SE, southeastern Barents Sea; NZ, Novaya Zemlya; FJ, Franz Josef Land. 
Kjellman (1877: 23) also expressed some doubts about the finding of $P$. elegans by J. Agardh during Rosenthal's expedition because he had no possibility to look at Agardh's collection and did not find this species when visiting Novaya Zemlya later. Vinogradova (2011: 683) reported P. plumosa in the Barents Sea on the Murman coast and the coast of the northern Norway; she characterized this species as an Atlantic element of the Arctic flora, entering only the border regions of the Arctic Ocean. Similarly, Membranoptera alata is known as an Atlantic species (Vinogradova 2011: 686). Zeller (1883: 105) reported this species as Delesseria alata probably from the southeastern coast of the Barents Sea, but without providing exact localities. This record, as well as a report of this species from Novaya Zemlya (Evseeva 2018: 20), is also doubtful because the authors have not confirmed it by voucher specimens.

Zinova (1953a, 1955) reported Devaleraea arctica (Halosaccion arcticum A.D. Zinova) from Spitsbergen. There is a specimen collected by Kjellman in 1872-1873 from Spitsbergen without providing exact localities in the LE collection, which is listed there as the syntype of H. arcticum (Mikhaylova and Sokolova 2020: 1115). The records of Coccotylus brodiei at Spitsbergen are based on old data without exact localities (Agardh 1862, 1868a; Børgesen and Jonsson 1908; Heuglin 1874; Kjellman 1875; Simmons 1906); the presence of this species in the Spitsbergen flora nowadays, in particular along the southeastern coast of Spitsbergen, requires verification. Therefore, these records cannot be confidently included in the checklist of Rhodophyta of the Barents Sea.

Seventeen algal species are widespread according to the analysis of the species distribution. Nine of them are found throughout the Barents Sea (Coccotylus truncatus, Devaleraea ramentacea, Euthora cristata, Lithothamnion glaciale, Meiodiscus spetsbergensis, Odonthalia dentata, Palmaria palmata, Phycodrys rubens, Savoiea arctica), three species are absent from Franz Josef Land (Fimbrifolium dichotomum, Membranoptera fabriciana, Ptilota serrata), and five absent from Bear Island (Grania efflorescens, Hildenbrandia rubra, Polysiphonia stricta, Ptilota gunneri, Rhodomela confervoides). Eleven species are distributed locally; two of them are recorded only on the Norwegian coast (Gaillona scopulorum, Kvaleya epilaeve), seven on the Murman coast (Colaconema leptonema, Erythrocladia polystromatica, Haemescharia hennedyi, Neopyropia leucosticta, Porphyropsis coccinea, Sahlingia subintegra, Stylonema alsidii). Rhodomela sibirica has been found only in the southeastern part, and Neopolyporolithon arcticum near Novaya Zemlya.
The short list of algae along Bear Island (Table 1) is undoubtedly explained by insufficient research of this region. That is the reason that these data have not been used in the comparative analysis of local floras. The Sørensen similarity index was calculated to examine the similarity of Rhodophyta floras among different regions of the Barents Sea. Unsurprisingly, the highest similarity is observed between the Norwegian and the Murman coasts (Table 2). Most species of the Murman coast were also found on the Norwegian coast of the Barents Sea except for the seven species mentioned above. It should be noted that five species, C. leptonema, $H$. hennedyi, $P$. coccinea, S. subintegra, and $S$. alsidii, were recorded on the western Norwegian coast (Rueness 1997), so one can expect to find them in northern Norway. High Sørensen similarity indices are also observed between Novaya Zemlya and three other regions: northern Norway, the Murman coasts, and the southeastern Barents Sea (Table 2). The comparatively rich flora of Novaya Zemlya includes $92.5 \%$ of the flora of the southeastern Barents Sea. Franz Josef Land is characterized by the poorest species composition (Table 1). Therefore, the Sørensen similarity indices between Franz Josef Land and all other regions of the Barents Sea are the lowest (Table 2).

Due to the lack of sufficient molecular genetic data on specimens from the Barents Sea, the morphological concept of species was applied in the present study. Recent molecular genetic studies have provided evidence on significant genetic diversity and the presence of cryptic species in southwest Norway and some regions of the Arctic Ocean, including in several genera of red algae (Bringloe et al. 2019, 2020). A similar pattern may be expected for the Barents Sea, which will change the similarity indices to some extent. However, with a unified approach to the analysis of the species composition of red algae within the Barents Sea, this comparison may be considered correct.

On a global scale, most of the species from the Barents Sea are circumpolar. The distribution patterns of 10 species

Table 2: Sørensen similarity index among the local floras of the Barents Sea, and (in brackets) the number of species common to each pair of regions.

\begin{tabular}{lrrrrr}
\hline Regions & NN & MC & SE & NZ & FJ \\
\hline SP & $0.60(31)$ & $0.57(31)$ & $0.65(24)$ & $0.67(27)$ & $0.58(16)$ \\
NN & & $0.94(69)$ & $0.71(40)$ & $0.78(47)$ & $0.47(22)$ \\
MC & & & $0.68(40)$ & $0.75(47)$ & $0.44(22)$ \\
SE & & & & $0.84(38)$ & $0.55(18)$ \\
NZ & & & & & $0.58(21)$ \\
\hline
\end{tabular}

Symbols: SP, Spitsbergen; NN, northern Norway; MC, Murman coast; SE, southeastern Barents Sea; NZ, Novaya Zemlya; FJ, Franz Josef Land. 
(Ceramium virgatum, Clathromorphum circumscriptum, Coccotylus brodiei, Fimbrifolium dichotomum, Membranoptera fabriciana, Ptilota gunneri, Rhodochorton purpureum, Rhodomela confervoides, Turnerella pennyi, Wildemania miniata) are clear northern extensions of North Atlantic populations (Bringloe et al. 2020; Vinogradova 1999). Only one species (Rhodomela sibirica) has a Pacific origin (Bringloe et al. 2020; Vinogradova 2005b, 2011).

The data presented in this paper are necessary background for further research. The information in Supplementary Table S1 allows searching easily for the original names and morphologically defined species in earlier publications. In addition, further development of molecular genetic methods will allow study of old specimens, preserved in the LE collection (Table 1, Supplementary Table S1).

The overview provided in the present study will serve as a definitive starting point for relevant molecular genetic studies, biogeographic research, and assessment of the impact of climate change on the biodiversity of red algae in the future. Finally, similar attention must be paid to the same issues for brown and green algae; when completed, this revision will bring a complete assessment of the diversity of macroalgae in the Barents Sea.

\section{Conclusion}

Nowadays, special attention is paid to obtaining a complete pattern of the biodiversity of the Arctic considering ongoing climate change. Only accurate data on the distribution of species in the past and present can be used in making projections of future distributional shifts of polar and cold-temperate seaweeds. In this paper, the list of Rhodophyta of the Barents Sea was thoroughly revised and discussed. A total of 82 valid species of red algae has been revealed by a comprehensive bibliographic search and considering current taxonomic and nomenclatural changes. Inaccurate records were found and corrected. The present revision has allowed the exclusion of unchecked and misidentified records for 36 species from the final checklist. By analyzing the distribution of the Rhodophyta in the Barents Sea, the widespread and restricted species were defined. These data are the starting point for relevant further molecular genetic studies and biogeographic research of the red algae in the Barents Sea.

Acknowledgments: The author thanks Dr. D. M. Martynova and A.V. Chaban for their support during the manuscript preparation. The present study was carried out within the framework of the institutional research project of the Komarov Botanical Institute of the Russian Academy of Sciences "Flora and taxonomy of algae, lichens and bryophytes in Russia and phytogeographically important regions of the world" (no. 121021600184-6).

Author contributions: The author has accepted responsibility for the entire content of this submitted manuscript and approved submission.

Research funding: The present study was carried out within the framework of the institutional research project of the Komarov Botanical Institute of the Russian Academy of Sciences "Flora and taxonomy of algae, lichens and bryophytes in Russia and phytogeographically important regions of the world" (no. 121021600184-6).

Conflict of interest statement: The author declares no conflicts of interest regarding this article.

\section{References}

Agardh, J.G. (1862). Om Spetsbergens Alger. Akademisk Program, Lund, p. 4.

Agardh, J.G. (1868a). Bidrag till kannedomen af Spetsbergens Alger. Kongl. Svenska Vet.-Akad. Handl. 7(8): 3-12.

Agardh, J.G. (1868b). Bidrag till kannedomen af Spetsbergens Alger. Tillagg till foregaende afhandling. Kongl. Svenska Vet.-Akad. Handl. 7(8): 27-49.

Averincev, V.G. and Vinogradova, K.L. (1990). Phytocenosis Halosaccion arcticum - Sphacelaria arctica at the Heis Island shoal (Franz Josef Land). Biol. Morya (Vladivost.) 3: 3-8 (in Russian with English abstract).

Averintseva, S.G. (1996). Vidovoj sostav i prostrnstvennoye raspredeleniye makrofitov [Species composition and spatial distribution of seaweeds]. In: Ecosistemy, bioresursy $i$ antropogennoye zagryazneniye Pechorskogo morya [Ecosystems, bioresources and anthropogenic pollution of the Pechora Sea]. Kola Scientific Center of the Russian Academy of Sciences, Apatity, pp. 79-88 (in Russian).

Averintseva, S.G. and Shoshina, E.V. (1990). Flora guby Yarnyshnoj Murmanskogo poberezhya Barentseva morya [Flora of the Yarnyshnaya inlet of the Murman coast of the Barents Sea]. Kola Scientific Center of the Russian Academy of Sciences, Murmansk, p. 15. (in Russian with English summary).

Blinova, E.I. (1964). Ecologo-floristicheskij ocherk guby Ivanovki reliktovogo vodoyema Barentseva morya [Ecological and floristic sketch of the Ivanovka inlet - a relict reservoir of the Barents Sea]. In: Zapasy morskikh rastenij $i$ ikh ispolzovaniye [Marine plant stocks and their uses]. Nauka, Moscow, pp. 58-70 (in Russian).

Blinova, E.I. (1965a). Epifity laminariyevykh Murmanskogo poberezhya Barentseva morya [Epiphytes of the laminarian algae of the Murman coast of the Barents Sea]. In: Raspredeleniye $i$ sostav promyslovykh vodoroslej Barentseva morya [Distribution and composition of commercial algae in the Barents Sea]. Nauka, Moscow-Leningrad, pp. 56-62 (in Russian).

Blinova, E.I. (1965b). Vertikalnoye raspredeleniye i kolichestvennij uchet makrofitov Aynovskikh ostrovov (Barentsevo more) 
[Vertical distribution and quantitative accounting of seaweeds of the Ainovsky Islands (the Barents Sea)]. In: Raspredeleniye $i$ sostav promyslovykh vodoroslej Barentseva morya [Distribution and composition of commercial algae in the Barents Sea]. Nauka, Moscow-Leningrad, pp. 41-55 (in Russian).

Blinova, E.I. (1966). Osnovniye tipy zaroslej vodoroslej litorali Murmana [The main types of the seaweed's thickets in the intertidal zone of the Murman coast]. Okeanologiya 6(1): 151-158 (in Russian).

Børgesen, F. and Jonsson, H. (1908). The distribution of the marine algae of the Arctic Sea and of the northernmost part of the Atlantic. In: Botany of the Faeröes, Vol. 3. Nordisk Forlag, Copenhagen. Appendix I-XXVIII.

Bringloe, T.T., Sjøtun, K., and Saunders, G.W. (2019). A DNA barcode survey of marine macroalgae from Bergen (Norway). Mar. Biol. Res. 15(10): 580-589.

Bringloe, T.T., Verbruggen, H., and Saunders, G.W. (2020). Unique biodiversity in Arctic marine forests is shaped by diverse recolonization pathways and far northern glacial refugia. Proc. Natl. Acad. Sci. Unit. States Am. 117(36): 22590-22596.

Ecologicheskij Atlas (2020). Barentsevo more [Ecological Atlas. The Barents Sea]. Fond “NIR", Moscow, p. 447 (in Russian).

Efimova, I.B. (1990). Winter complex of algal epiphytes on the Murman littoral (the Barents Sea). Bot. Zhurn. 75: 351-358 (in Russian).

Efimova, I.B. (1995). Addition to the marine algal flora of Arctic seas of Russia. Bot. Zhurn. 80: 97-100 (in Russian).

Evseeva, N.V. (2018). Species composition of seaweeds of the coastal zone of the Murmansk coast and archipelago Novaya Zemlya. Tr. VNIRO 171: 7-25 (in Russian with English abstract).

Flerov, B.C. (1932). Algues des côtes de la Nouvelle Zemble. I. Distribution des Algues sur les côtes de la Nouvelle Zemble. Trans. Oceanogr. Inst. 2(1): 7-45, 76-87 (in Russian with extended French resume).

Flerov, B.C. and Karsakoff, N. (1925). Algues de la règion sud-est de la mer de Barents (mer de Petchora). Berichte des Wissenschaftlichen Meeresinstituts 15: 3-17 (in Russian with extended French resume).

Flerov, B.C. and Karsakoff, N.W. (1932). Algues des côtes de la Nouvelle Zemble. II. Liste des Algues de la Nouvelle Zemble. Trans. Oceanogr. Inst. 2(1): 46-73, 88-92 (in Russian with extended French resume).

Foslie, M. (1881). Om nogle nye arctiske havalger. Christiania Vidensk.-Selsk. Forhandl. 14: 1-14.

Foslie, M. (1890). Contribution to the knowledge of the marine algae of Norway. I. East Finmarken. Troms $\varnothing$ Mus. Aarsh. 13: 1-186.

Fredriksen, S., Karsten, U., Bartsch, I., Woelfel, J., Koblowsky, M., Schumann, R., Moy, S.R., Steneck, R.S., Wiktor, J.M., Hop, H., et al. (2019). Biodiversity of benthic macro- and microalgae from Svalbard with special focus on Kongsfjorden. In: Hop, H. and Wiencke, C. (Eds.), The ecosystem of Kongsfjorden, Svalbard. Advances in polar ecology, Vol. 2. Springer, Cham, pp. 331-371.

Gemp, K.P. and Byzova, L.N. (1970). Vodorosli proliva Karsliye Vorota (Yuzhnoye poberezhye Novoj Zemli) [Algae of the Kara Strait (southern coast of Novaya Zemlya)]. Materialy rybokhozaystvennykh issledovaniy Severnogo basseyna [Mater. Fish. Stud. N. Basin] 13: 102-110 (in Russian).

Gobi, C. (1878). Die Algenflora des Weissen Meeres und der demselben zunächstliegenden Theile des Nördlichen Eismeeres. Mém. Acad. Imp. Sci. Saint Pétersbourg, Sér. 7(26): 1-92.
Golikov, A.N. and Averincev, V.G. (1977). Biocoenoses of the upper regions of the shelf of Franz Josef Land archipelago and some regularities of their distribution. Explorations of the Fauna of the Seas. Zool. Inst. Akad. Nauk S.S.S.R. 14(22): 5-54 (in Russian).

Grintal, A.R. (1965). Sostav i raspredeleniye soobshchestv vodoroslej na litorali gub Yarnyshnoj i Podpakhty (Vostochnij Murman) [Composition and distribution of algal communities in the intertidal zone of the Yarnyshnaya and Podpakhty inlets (East Murman)]. In: Raspredeleniye i sostav promyslovykh vodoroslej Barentseva morya [Distribution and composition of commercial algae in the Barents Sea]. Nauka, Moscow-Leningrad, pp. 23-40 (in Russian).

Guiry, M.D. and Guiry, G.M. 2021. AlgaeBase. World-wide electronic publication, National University of Ireland, Galway. Available at: http://www.algaebase.org (Accessed March 2021).

Heuglin, M.Th. (1874). Beitrage zur Fauna, Flora und Geologie von Spitsbergen und Novaya Semlja. Drud und Berlag von George Heftermann, Braunschweig, p. 352.

Jaasund, E. (1965). Aspects of the marine algal vegetation of North Norway. Elanders Boktryckeri Aktiebolag, Göteborg, p. 174.

Kjellman, F.R. (1875). Om Spitsbergens marina, klorofyllförande Thallophyter. I. Bih. K. Svenska Vet. Acad. Handl. 3(7): 1-34.

Kjellman, F.R. (1877). Ueber die Algenvegetation des Murmanischen Meeres an der Westküste von Nowaja Semlja und Wajgatsch. Nova Acta reg. Soc. Sc. Upsal. 3: 1-86.

Kjellman, F.R. (1883). The algae of the Arctic Sea. A survey of the species together with an exposition of the general characters and their development of the flora. Kongl. Svenska VetenskapsAkadem. Handl. 20(5): 1-350.

Kjellman, F.R. (1903). Über die Meeresalgen-Vegetation von Beeren Eiland. Arkiv. Bot. 1: 1-6.

Korennikov, S.P. and Gemp, K.P. (1976). On the species composition of sublittoral marine algae of the Kanin peninsula coast locality. Bot. Zhurn. 61: 561-565 (in Russian).

Korennikov, S.P. and Shoshina, E.V. (1980). Composition and distribution of algae in the Southeastern Barents Sea between the Cape Mikhulkin to the Cape Russky Zavorot. Bot. Zhurn. 65: 855-859 (in Russian).

Kucheruk, N.V., Kotov, A.V., Maximova, O.V., Pronina, O.A., Sapozhnikov, F.V., and Malykh, E.A. (2003). Bentos [Benthos]. In: Romankevich, E.A., Lisitsin, A.P., and Vinogradov, M.E. (Eds.), Pechorskoye more: Sistemniye issledovaniya (Gidrofizika, gidrologiya, optika, biologiya, khimiya, geologiya, ecologiya, sotsio-economicheskiye problemy) [Pechora Sea: systemic research (Hydrophysics, hydrology, optics, biology, chemistry, geology, ecology, socio-economic problems)]. More, Moscow, pp. 217-230.

Kuznetsov, L.L. and Schoschina, E.V. (2003). Phytocenoses of the Barents Sea (physiological and structural characteristics). KSC RAS, Apatity, p. 308 (in Russian).

Lindblom, A.E. (1840). Förtekning öfver de på Spetsbergen och Beeren Eiland anmärkta vexter; af Utgifvaren. Bot. Not. 9: 153-158.

Magurran, A.E. (1988). Ecological diversity and its measurement. Princeton University Press, Princeton, NJ, p. 179.

Makarov, V.N. and Shoshina, E.V. (1986). Vodorosli-makrofity Barentseva morya [Barents Sea macrophyte algae]. In: Matishov, G.G. (Ed.), Zhizn i usloviya eye sushchestvovaniya $v$ bentali Barentseva morya [Life and conditions of its existence in the benthal of the Barents Sea]. USSR Academy of Sciences, Apatity, pp. 52-67. 
Malavenda, S.V. (2018). Macroalgae's flora of the Kola Bay (the Barents Sea). Vestn. Murmanks Technical Univ. 21(2): 245-252 (in Russian with English abstract).

Malavenda, S.V. and Makarov, M.V. (2014). The structure of sublittoral phytocenoses in wave-protected bay Zelenetskaya, Murman coast, Barents sea. Issues Mod. Algol. 1(5), Available at:http:// algology.ru/472 (in Russian with English abstract).

Malavenda, S.V. and Metelskiy, A.A. (2013). Assotsiatsii laminariyevykh vodoroslej gub Ivanovskaya i Drozdovka Vostochnogo Murmana [Associations of the kelp algae of Ivanovskaya and Drozdovka inlets of the East Murman]. Vestn. Murmanks Technical Univ. 16(3): 493-500 (in Russian with English abstract).

Malavenda, S.V., Shoshina, E.V., and Kapkov, V.I. (2017). Species diversity of seaweeds in different areas of the Barents Sea. Vestn. Murmanks Technical Univ. 20(2): 336-351 (in Russian with English abstract).

Markovskaya, E.F., Malavenda, S.V., Ryzhik, I.V., Sergiyenko, L.A., Sonina, A.V., Starodubtseva, A.A. and Voskoboynikov, G.M. (2016). Rasteniya i lishayniki Murmanskogo poberezhya Barentseva morya (polevoj atlas) [Plants and lichens of the Murmansk coast of the Barents Sea (field atlas)]. Petrozavodsk, p. 191 (in Russian).

Metelskiy, A.A. (2014). On the flora of the Pechora Sea macroalgae. Vestn. Yzhnogo nauchnogo tsentra. 10(1): 50-54 (in Russian with English abstract).

Mikhaylova, T.A. (2006). Rodomela sibirica A. Zin. et Vinogr. In: Matveeva, N.V. (Ed.), Krasnaya Kniga Nenetskogo Avtonomnogo Okruga [Red book of the Nenets Autonomous area]. Nenets Information and Analytical Center, Naryan-Mar, p. 107 (in Russian).

Mikhaylova, T.A. (2012). Laminaria hyperborea (Laminariaceae) association on the Murman coast of the Barents Sea. Bot. Zhurn. 91: 712-729 (in Russian with English summary).

Mikhaylova, T.A. and Shtrik, V.A. (2007). Macroepiphytes of Laminaria hyperborea (Laminariaceae) in the Barents and the White Seas. Bot. Zhurn. 92: 1818-1828 (in Russian with English summary).

Mikhaylova, T.A. and Sokolova, I.V. (2020). Type and authentic specimens in Algal Herbarium of the Komarov Botanical Institute (LE). II. Bot. Zhurn. 105: 1114-1126.

Perestenko, L.P. (1963). Algae pro Murmano novae. Bot. Mater. Otd. Sporov. Rast. Bot. Inst. Komarova Akad. Nauk S.S.S.R. 16: 69-72 (in Russian).

Perestenko, L.P. (1964). Index algarum litorum sinuum Plochije et Boljschie Czevry (Murmanus Orientalis). Nov. Sist. Nizshikh Rast. 1: 139-146 (in Russian).

Perestenko, L.P. (1983). De genere Phycodrys Kiitz. et proprietatibus eius notula. Nov. Sist. Nizshikh Rast. 20: 45-51 (in Russian).

Postels, A. and Ruprecht, F. (1840). Illustrationes algarum in itinere circa orbem jussu Imperartoris Nicolai I. atque auspiciis Navarchi Friderici Lütke annis 1826, 1827, 1828 et 1829, celoce Seniavin executo in Oceano Pacifico, imprimis septemtrionalio ad littora Rossica Asiatico-Americana collectarum. Typis Eduardi Pratz, Petropoli [St. Petersburg], p. 22.

Pushkin, A.F. (1968). Donniye soobshchestva Choshskoj guby [Bottom communities of the Cheshskaya Inlet]. In: Gidrobiologicheskiye issledovaniya $v$ pribrezhnykh rayonakh Barentseva morya [Hydrobiological research in the coastal areas of the Barents Sea]. Nauka, Leningrad, pp. 48-57 (in Russian).

Rueness, J. (1977). Norsk Algeflora. Universitetsforlaget, Oslo-BergenTromsö, p. 266.
Rueness, J. (1997). Algae. In: Brattegard, T. and Holthe, T. (Eds.), Distribution of marine, benthic macro-organisms in Norway. $A$ tabulated catalogue. Preliminary Edition. Research Report No. 1997-1. Direktoratet for Naturforvaltninhg, Trondheim, pp. 1-394.

Schneider, C.W. and Wynne, M.J. (2007). A synoptic review of the classification of red algal genera a half century after Kylin's "Die Gattungen der Rhodophyceen”. Bot. Mar. 50: 197-249.

Schoschina, E.V. (1996). Seasonal and age dynamics of growth and reproduction of Phycodrys rubens (Rhodophyta) in the Barents and White Seas. Aquat. Bot. 55: 13-30.

Schoschina, E.V. (1998). Seasonal growth and reproduction of Palmaria palmata (Rhodophyta) on the Murman coast of the Barents Sea. Bot. Zhurn. 83: 46-55 (in Russian with English summary).

Schrenk, A. (1854). Reise nach den Nordosten des europäischen Russlands durch die Tundren der Samojeden zum Arctischen Uralgebirge in Jahre 1837 ausgeführt. Druck von Heinrich Laakmann, Dorpat, p. 552.

Sewell, P. (1889). The flora of the coasts of Lapland and of the Yugor Straits, as observed during the voyage of the "Labrador" in 1888 , with summarized list of all the species known from the islands of Novaya Zemlya and Waigatz, and from the north coast of western Siberia. Trans. Bot. Soc. 17: 444-481.

Shirshov, P.P. (1933). An outline of the distribution of algae in the Krestovaya Bay on Novaya Zemlya. Trudy Arkticheskogo Instituta [Proc. Arctic Inst.] 7: 9-39 (in Russian).

Shoshina, E.V. (1991). Growth of the red alga Odonthalia dentata in the Barents and White seas. Biol. Morya (Vladivost.) 6: 15-22 (in Russian with English abstract).

Shoshina, E.V. and Averintseva, S.G. (1994). Raspredeleniye assotsiatsij vodoroslej, vidovoj sostav i biomassa v gube Yarnyshnoj Barentseva morya [Distribution of algal associations, species composition and biomass in Yarnyshnaya Inlet, Barents Sea]. In: Gidrobiologicheskiye issledovaniya v zalivakh $i$ bukhtakh severnykh morej Rossii [Hydrobiological studies in the bays and bights of the northern seas of Russia]. USSR Academy of Sciences, Apatity, pp. 38-61 (in Russian).

Shoshina, E.V. and Makarov, V.N. (1995). Benthos. Macrophytes. In: The biological resources of the coastal zone of the Kola Peninsula. Modern state and rational use. USSR Academy of Sciences, Apatity, pp. 74-82 (in Russian).

Shoshina, E.V., Voskoboinikov, G.M., and Makarov, V.N. (1994). The value of macrophytes belt state in the Teriberskaya bay of the Barents Sea (materials to valuation of influence of exploitation of Schtokman gas-condense deposit on environment). USSR Academy of Sciences, Apatity Lexington, KY, Apatity, p. 30 (in Russian).

Shtric, V.A., Vozzhinskaya, V.B., and Vekhov, N.V. (2000). Seaweeds of the Novaya Zemlya and Yugorsky Shar Strait Coasts. In: Morskiye gidrobiologicheskiye issledovaniya [Marine hydrobiological researches]. VNIRO, Moscow, pp. 88-98 (in Russian with English abstract).

Simmons, H.G. (1906). Remarks about the relations of the floras of the Northern Atlantic, the Polar Sea, and the Northern Pacific. Beih. Bot. Centralbl. 19(2): 149-194.

Sinova, E.S. (1912). Algae Murmanicae. I. Chlorophyceae et Rhodophyceae. Trudy Imp. S.-Peterburgsk. Obshch. Estestvoisp. 43(3): 171-343 (in Russian).

Sinova, E.S. (1914). Algae Murmanicae. II. Phaeophyceae. Trudy Imp. Petrogradsk. Obshch. Estestvoisp., Vyp. 3(44-45): 213-326 (in Russian). 
Sinova, E.S. (1916a). Note sur les forms de Ptilota plumosa (L.) Ag. et Ptilota Californica Rupr., recueillies aux côtes polaires de la Russie d'Europe. Izv. Glavn. Bot. Sada R.S.F.S.R. 16(2): 416-424 (in Russian with French resume).

Sinova, E.S. (1916b). Note sur une algue rare marine des Rhodophycées - Delesseria fimbriata De la Pyl. Izv. Glavn. Bot. Sada R.S.F.S.R. 16(1): 139-144 (in Russian with French resume).

Sinova, E.S. (1926). Die neue Entdeckungen in die Algenflora von Murmanische Küsten. Tr. Leningr. Obshchestva Estestvoispyt. 56(3): 17-44 (in Russian with German summary).

Sinova, E.S. (1929). Algues de la Novaja Zemlja. Explorations des mers d'U.R.S.S. 10: 41-128 (in Russian with French summary).

Sinova, E.S. (1933). Algues de Mourmane aux environs de l'île Kildine et leur utilization. Explorations des mers d'U.R.S.S. 18: 49-74 (in Russian with French summary).

Sinova, E.S. (1956). Algae Oceani Glacialis Arctoi. Trudy Bot. Inst. Akad. Nauk S.S.S.R. Ser. 2, Sporov. Rast. 11: 39-51 (in Russian).

Terechova, T.K. (1973). Algae archipelagi Terrae Franz-Joseph. Nov. Sist. Nizshikh Rast. 10: 68-70 (in Russian).

Vinogradova, K.L. (1961). Species algarum pro Murmano novae. Bot. Mater. Otd. Sporov. Rast. Bot. Inst. Komarova Akad. Nauk S.S.S.R. 14: 91-93 (in Russian).

Vinogradova, K.L. (1964a). Index algarum ad litora Insularum Ainov (Litus Murmanicum) lectarum. Nov. Sist. Nizshikh Rast. 1: 120-125 (in Russian).

Vinogradova, K.L. (1964b). Species algarum pro Murmano novae. II. Nov. Sist. Nizshikh Rast. 1: 114-119 (in Russian).

Vinogradova, K.L. (1986). Compositio specierum algarum apchipelagi Terrae Franz-Joseph. Nov. Sist. Nizshikh Rast. 23: 27-37 (in Russian).

Vinogradova, K.L. (1987). Some features of benthos algal flora from Franz Josef Land Archipelago. Bot. Zhurn. 72: 1203-1206 (in Russian).

Vinogradova, K.L. (1999). De distribution algarum-macrophytorum in maribus Rossiae arcticis notula. Nov. Sist. Nizshikh Rast. 33: 14-24 (in Russian).

Vinogradova, K.L. (2002). Phycodrys rubens (Delesseriaceae, Rhodophyta): taxonomy, relationships, distribution. Bot. Zhurn. 87: 139-148 (in Russian with English summary).

Vinogradova, K.L. (2005a). Ceramium species (Ceramiales, Rhodophyta) in the Russian northern seas. Bot. Zhurn. 90: 884-890 (in Russian with English summary).

Vinogradova, K.L. (2005b). The genus Rhodomela (Rhodomelaceae, Rhodophyta) in the flora of northern seas of Russia. Bot. Zhurn. 90: 1047-1057 (in Russian with English summary).

Vinogradova, K.L. (2007). The genus Porphyra (Bangiales, Rhodophyta) in the northern seas of Russia. Bot. Zhurn. 92: 532-543 (in Russian with English summary).

Vinogradova, K.L. (2010). Taxonomic review of the Corallinales (Rhodophyta) in the northern Russian seas. Bot. Zhurn. 95: 667-681 (in Russian with English summary).

Vinogradova, K.L. (2011). The order Ceramiales (Rhodophyta) in the flora of the Arctic Ocean. Bot. Zhurn. 96: 681-695 (in Russian with English summary).

Vinogradova, K.L., and Shoshina, E.V. (1993). Algae. In: Matishov, G.G., Galaktionov, K.V., Denisov, V.V., Drobysheva, S.S., Chinarina, A.D., and Timofeeva, S.V. (Eds.), Environment and ecosystems of the Franz Josef Land (Archipelago and shelf). KSC RAS Press, Apatity, pp. 109-116.
Vinogradova, K.L. and Shtrik, V.A. (2005). Additions to the marine algae flora of the northern seas of Russia. Bot. Zhurn. 90: 1593-1599 (in Russian with English summary).

Weslawski, J.M., Zajaczkowski, M., Wiktor, J. and Szymelfenig, M. (1997). Intertidal zone of Svalbard: 3. Littoral of a subarctic, oceanic island: Bjornoya. Polar Biol. 18: 45-52.

Wynne, M.J. and Schneider, C.W. (2010). Addendum to the synoptic review of red algal genera. Bot. Mar. 53: 291-299.

Zeller, G. (1883). Algen und Zoophyten in Nordischen Meer und Sibirien gesammelt von Graf Waldburg-Zeil. Jahresh. Ver. vaterl. Naturkd. Württemb. 39: 104-106.

Zinova, A.D. (1935). Algues de Mourman aux environs de l'île Maly Olény (Nemetzkij). Explorations des mers D’U.R.S.S. Institut Hydrologique. 21: 88-97 (in Russian with French resume).

Zinova, A.D. (1948). 0 nekotorykh vidakh roda Porphyra s beregov Murmana i Belogo morya i o novom vide Porphyra helenae Zin [On some species of the genus Porphyra from the shores of the Murman and the White Sea and on the new species Porphyra helenae Zin]. Bot. Zhurn. 33: 440-442 (in Russian).

Zinova, A.D. (1950). 0 nekotorikh osobennostyakh flory vodoroslej Belogo morya [On the certain features of the flora of the White Sea algae]. Trudy Vsesoyuzn. Gidrobiol. Obshch. 2: 231-252 (in Russian).

Zinova, A.D. (1953a). De alga Rhodophytica nova e genere Halosaccion. Bot. Mater. Otd. Sporov. Rast. Bot. Inst. Komarova Akad. Nauk S.S.S.R. 9: 83-95 (in Russian).

Zinova, A.D. (1953b). Notae ad floram algarum litoris Murmanici. Bot. Mater. Otd. Sporov. Rast. Bot. Inst. Komarova Akad. Nauk S.S.S.R. 9: 84-93 (in Russian).

Zinova, A.D. (1955). Opredelitel krasnykh vodoroslej severnykh morej SSSR [Determination book of the red algae of the northern seas of the USSR]. Akad. Nauk SSSR, Moscow-Leningrad, p. 220. (in Russian).

Zinova, A.D. (1961a). De alga rubra Dilsea integra (Kjellm.) Rosenv. Notula. Bot. Mater. Otd. Sporov. Rast. Bot. Inst. Komarova Akad. Nauk S.S.S.R. 14: 82-86 (in Russian).

Supplementary Material: The online version of this article offers supplementary material (https://doi.org/10.1515/bot-2021-0011).

\section{Bionote}

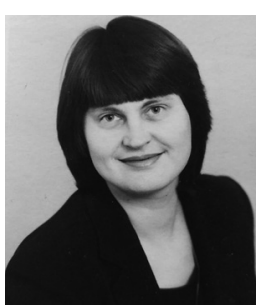

Tatiana A. Mikhaylova

Department of Algology, Komarov Botanical Institute, Russian Academy of Sciences, Professora Popova Str., 2, Saint Petersburg 197376, Russia TMikhaylova@binran.ru https://orcid.org/0000-0002-4740-0437

Tatiana A. Mikhaylova is a head of the Laboratory of Algology of Komarov Botanical Institute. She received her PhD in 2000 under Dr. K. Vinogradova at Komarov Botanical Institute of the Russian Academy of Sciences, Saint Petersburg, Russia. Her main research interests are floristics, marine ecology, and taxonomy of seaweeds. 